\title{
A VIOLENT LEGACY: POLICING INSURRECTION IN SOUTH AFRICA FROM SHARPEVILLE TO MARIKANA
}

\author{
Bill Dixon \\ Professor of Criminology \\ School of Sociology and Social Policy \\ University of Nottingham \\ Law and Social Sciences Building \\ University Park \\ Nottingham \\ NG7 2 RD \\ Tel: 01159515403 \\ Fax: 01159515232 \\ Email: william.dixon@nottingham.ac.uk
}

Fifty-two years separate the fatal shootings by police of 69 anti-apartheid protestors at Sharpeville on $21^{\text {st }}$ March 1960 and of 34 striking miners at Marikana on $16^{\text {th }}$ August 2012. The parallels between the two 'massacres' are easy to overstate; but both involved the use of lethal violence by the police against people taking part in insurrectionary action. Drawing on Marenin's (1982) work on the relative autonomy of the police, this paper argues that events at Marikana have to be seen in the context of South Africa's failure to tackle the structural violence of apartheid and the use of direct, personal violence by the police before and since the country became a constitutional democracy in 1994.

Keywords: South Africa, violence, police, Marikana

On 21 $1^{\text {st }}$ March 196069 people were killed and more than 300 injured when members of the South African Police (SAP) opened fire on a crowd that had assembled in the township of Sharpeville near Vereeniging south of Johannesburg to protest against the apartheid pass laws. The Truth and Reconciliation Commission (TRC) found that 'the police deliberately opened fire on an unarmed crowd'. ${ }^{1}$ They failed to order the crowd to disperse before opening fire and continued shooting when people turned to flee. Many of the victims of the massacre were shot in the back. Just over 52 years later, on $16^{\text {th }}$ August 2012, 34 strikers from a platinum mine in Marikana not far from Rustenburg north-west of Johannesburg were shot dead by the South African Police Service (SAPS). More than 70 people were injured. Ten others had died in the days leading up to $16^{\text {th }}$ August. The precise circumstances in which the shootings took place were the subject of a Commission of Inquiry led by a retired judge of South Africa's Supreme Court of Appeal, lan Farlam. ${ }^{2}$

Media and academic observers have joined lawyers appearing before the Farlam Commission in pointing out the parallels between the two 'massacres' (Smith 2012; Frankel 2013: 25-6; Maromo 
2014). Both have been described as turning points or ruptures: Sharpeville in the history of apartheid South Africa (Frankel 2001; Lodge 2011); Marikana in the development of the country's new democracy (Frankel 2013; Alexander 2013). With the benefit of half a century of hindsight, Lodge (2011: v) refers to Sharpeville's 'generally received status as an historical dividing point'. Calland (2013: 25), writing less than a year after the shootings occurred, is equally forthright: 'Thirtyfour people were shot dead, and South Africa changed forever'. Hart (2013: 2) offers a similarly apocalyptic assessment:

The Marikana massacre was the single most traumatic event of the post-apartheid era, evoking images and memories of police brutality at Sharpeville in 1960 and the Soweto Uprising in 1976. Along with the corpses, hopeful visions of a new South Africa lay shattered on the killing fields of Marikana.

Others take exception to such comparisons (Moyo 2013); and, as those who make them would readily concede, the change in government from white minority rule to multi-racial democracy that took place in 1994 cannot be ignored in understanding the context in which the two massacres took place. Yet the fact that the SAPS members who killed the strikers at Marikana did so under a democratically elected government rather than as the enforcers of white minority rule begs as many questions as it answers.

My purpose in this article is to ask, and attempt to respond to, the most obvious and important of these questions: how could it be that, 18 years into South Africa's new democracy, the police stand accused of shooting 34 people, a substantial number of them, it appears, in the back and in cold blood (Alexander 2012: 40; Ledwaba 2013: 61-5). In an earlier attempt to explore the implications of the events at Marikana on and immediately before $16^{\text {th }}$ August 2012 (Dixon 2013), I drew on Otwin Marenin's (1982) notion of the 'relative autonomy' of the police to warn against reading too much into the relationship between the SAPS, the state and ruling elites, and misunderstanding the nature of their everyday interactions with the public as a result. I argued that what the police do as agents of what Marenin called 'specific domination' responding to strikes, service delivery protests (of which more below) and other politically charged incidents on behalf of socially dominant groups may tell us surprisingly little about the way in which they discharge their function as guarantors of a more 'general order' in the interests of all citizens, the ruled as well as the rulers (Dixon 2013: 7). On a reading of recent ethnographic studies of everyday policing on township streets (Steinberg 2008) and in the high-rise slums of the inner city (Hornberger 2011), I suggested that the state's writ may not run as far as some commentators on the Marikana shootings might believe. 
What I want to do here is to look more closely at the other side of the coin and to argue that, much as the 'old' SAP did at Sharpeville in 1960 - and on so many other occasions more or less from the day it was established on 1 April 1913 - the 'new' SAPS resorts all too readily to the use of excessive, and often lethal, force in the face of what the police, their leaders and members of local and national elites see as insurrectionary action. By 'insurrection' I mean, as the Shorter Oxford English Dictionary has it, 'the action ... of rising against authority or government'. In the case of Sharpeville, the insurrectionary nature of the protests lay in the centrality of the pass laws to the regime's ability to control subaltern populations. Large-scale protests against these laws organised by Africanist militants in a hitherto stable and well-ordered township in the industrial heartlands of the Vaal Triangle posed a threat to the whole edifice of apartheid. They could not be allowed to continue unchecked. In Marikana, the action of the strikers represented a multi-faceted challenge to the foundations of the post-apartheid economic and political dispensation: to the ability of the mine's owners, Lonmin, to operate the mine at a profit; to South Africa's ability to attract foreign investment; to the dominance in the mining industry of the National Union of Mineworkers, an affiliate of the Congress of South African Trade Unions (COSATU) (itself a partner of the ruling African National Congress (ANC) in a tri-partite alliance with the South African Communist Party (SACP)); and finally to the political hegemony of the ANC at a time when it was struggling to control a revolt by the former president of its Youth League, Julius Malema. ${ }^{3}$

If we are to understand why the SAPS acted against the striking miners at Marikana in the way that it did, I will argue that the events of $16^{\text {th }}$ August 2012 have to be seen in the context of South Africa's attempts to deal with the violence of apartheid exemplified by the killings at Sharpeville over half a century earlier. In doing so, I will focus on two related forms of violence. I will look first at the structural violence of apartheid and the system of migrant labour on which the colonial and apartheid mining economies were based. Secondly, and more specifically, I will consider the use of personal violence by the police in managing the effects of injustice and inequality, and responding to popular protests against them.

\section{The structural violence of apartheid}

Reflecting on the persistence and pervasiveness of social violence during the period of South Africa's transition to democracy from 1990, Brandon Hamber (1998) draws attention to the social and structural factors that underpin it. The victims of apartheid, he argues, suffered arbitrary arrests, beatings, assassinations and torture. But this was not all, for they were also 'subjected to the structural and systematic violence of poverty, malnutrition, inferior education, urban overcrowding and social strife' (Hamber 1998: unpaginated) . Although he describes this underlying condition as involving 'structural violence' he makes no reference to the origins of the term. These lie in the 
work of the American peace researcher, Johan Galtung (1969: 171), who distinguishes between the direct, personal violence inflicted, for example, when the police arrest, beat, torture or kill and the indirect structural violence that 'shows up as unequal power and consequently as unequal life chances'. Galtung (1969: 171, emphasis in original) summarises the main features of structural violence thus:

Resources are unevenly distributed, as when income distributions are heavily skewed, literacy/education unevenly distributed, medical services existent in some districts and for some groups only, and so on. Above all the power to decide over the distribution of resources is unevenly distributed. ${ }^{4}$

These two sentences provide an admirable summary of the economic, social and political structure of apartheid South Africa.

But to return to Hamber (1998: unpaginated), the main point of his argument is that the notion of reconciliation central to South Africa's transition to democracy would not deliver on the promise of peace if the 'deep-rooted inequities and social imbalances' of apartheid remained unaddressed. The main institutional mechanism for coming to terms with the legacy of apartheid, and for bringing about reconciliation in a democratic South Africa, was the TRC. Yet, as many authors not unsympathetic to the TRC and attentive to the limitations imposed on it by its legislative mandate and the nature of the country's negotiated transition to democracy, have noted, the Commission failed to grapple in any systematic way with the apartheid system in all its complexity leaving it to form a blurred and under-analysed background to the gross violations of human rights that were the main focus of the TRC's work (see, for example, Posel 2002; Simpson 2002; Gready 2011). Institutional hearings (including one on the business sector) were held in an effort to bring the workings of apartheid into sharper focus, but Deborah Posel (2002: 163) concludes that the TRC's final report offers little in the way of serious historical analysis and sheds no fresh light on its social, ideological and institutional features. Even where the TRC's mandate did extend to attempting to right the wrongs of apartheid in a material way, it was able to do no more than recommend a programme of reparations for the individual victims of gross human rights violations and it was not until late 2003 that the then government began to make final lump sum payments of R30, 000 (or approximately $\$ 4,000)$ - an amount that was considerably lower than the Commission had initially suggested (Gready 2011). In the final analysis, then, it went some way beyond both the mandate and the capacity of the TRC to tackle the rampant injustices and inequities bequeathed to the new democracy by apartheid and the primary responsibility for translating the rhetoric of reconciliation into reality, and tackling the structural violence of apartheid, has rested with the governments elected since 1994. It is to the social and economic policies of those governments that we must turn 
if we are to understand what has gone wrong, and why, twenty years on, resources continue to be so unevenly distributed, and the power to decide on their distribution so concentrated in the hands of a new, partially reconstituted elite.

\section{Post-apartheid political economy}

Prompted perhaps by the twentieth anniversary of the 1994 elections, the political economy of postapartheid South Africa has received a good deal of critical attention in recent year years (Marais 2011; Terreblanche 2012; Habib 2013; Hart 2013; Bundy 2014; Saul and Bond 2014). Despite some inevitable differences in emphasis among authors from a range of disciplinary backgrounds and ideological positions, this body of work offers an account of the efforts made by successive governments to bind up the socio-economic wounds of apartheid that is broadly consistent and provides an important insight into why patterns of structural violence evident at Sharpeville in 1960 are not hard to detect in contemporary Marikana. What follows here is an attempt to provide a rough chronology of developments over the last 20 years and to place the Marikana shootings in the wider context of a post-apartheid political economy in which the minerals-energy complex (MEC) continues to play an influential if not dominant role. ${ }^{5}$

The story begins in the late 1980s when, according to Sampie Terreblanche (2012), representatives of the MEC set about the task of orchestrating the transformation of South Africa's politicoeconomic system. Baldly stated, their objective was to ensure that, whatever political settlement was reached between the ANC and the outgoing National Party government, the economy would continue to be dominated by 'capitalist/corporatist' interests (Terreblanche 2012: 68). While public negotiations over a new constitutional dispensation took place through the Convention for a Democratic South Africa (CODESA) in the years leading up to 1994, a parallel set of secret discussions were being held during the course of which the leaders of national and global capital sought to "box in' the ANC so that 'it would not be possible for an ANC government to pursue socialist, populist or redistributive policies' (Terreblanche 2012: 68). In return, opportunities were offered to the 'emerging ANC elite' to buy into the commanding heights of the economy by means of black economic empowerment and affirmative action and procurement, and to begin to enjoy the affluent lifestyles of their white counterparts (Terreblanche 2012: 69).

Although others are more sympathetic to the ANC in their accounts of this critical period in the evolution of the post-apartheid politico-economic system, there is a broad measure of agreement among recent commentators that, by the time the ANC-led Government of National Unity took office 1994, the leadership of the main liberation movement had been seduced and/or coerced into accepting the terms offered by capital, with domestic and international representatives of the MEC 
very much to the fore. For Ronnie Kasrils (2013), a stalwart of the anti-apartheid struggle, a member of ANC's National Executive Committee for 20 years and a cabinet minister from 2004 to 2008, the 'Faustian moment' came just before the 1994 elections when a secret loan of $\$ 850$ million from the International Monetary Fund was accepted 'with strings attached that precluded a radical economic agenda'. In any event, the careful ambiguities of the Reconstruction and Development Programme (RDP) published in February 1994 were resolved two years later in favour of a Growth, Employment and Redistribution (GEAR) strategy that made no bones about South Africa's commitment to the basic tenets of global neo-liberalism: fiscal conservatism, privatisation, deregulation and a growth path dependent on the private sector, exports and the confidence of foreign investors (Bundy, 2014: 37).

In six short years the ANC's economic policy set off from a socialist platform, chugged briefly along a social democratic branch line, but ultimately steamed into Neo-liberal Central.

(Bundy: 2012: 33-4)

Some cautious steps back towards a more interventionist position and higher levels of expenditure on social grants and public works were taken from the early 2000s first under Thabo Mbeki and then when he was replaced as President, eventually by his erstwhile Deputy, Jacob Zuma, following the ANC's elective conference at Polokwane in 2007. There was talk of South Africa as a 'developmental state' modelled on the newly industrialised economies of East and South-East Asia during this period but, as Hein Marais (2011: 339) observes:

The post-apartheid development path, once analysed, does not escape the description 'neoliberal', nor do high levels of public spending transform the country into a developmental state.

Taking stock of these developments in his recent book on the changing face of power in South Africa, Richard Calland (2013: 13-20) provides a useful assessment of the 'state of the nation' towards the end of the second decade of democracy. A review of key socio-economic indicators leads him to draw two broad conclusions. The first is that living conditions have improved since 1994 . The HIV/AIDS pandemic reduced life expectancy by 15 per cent between 1990 and 2010 but there were significant improvements in adult literacy, child mortality and access to sanitation and potable water. Mainly thanks to the extension of social grants (the value of which increased from 2.9 to 3.5 per cent of GDP between 2003/4 and 2010/11), the proportion of people living in absolute poverty on less than two US dollars a day has declined, though there is some disagreement as to the extent of the reduction. His second conclusion is that South Africa has become an even more unequal society than it was in the final years of apartheid. The Gini coefficient (the standard statistical 
measure of inequality) worsened between 1995 and 2009, while the income shares of the top 10 per cent of earners and the bottom 20 have moved in opposite directions over the same period, the former's rising by 6.6 points, the latter's falling by 0.9 . Participation in key areas of economic activity has changed with a $325 \%$ rise in the proportion of senior and executive management positions occupied by black (African, Indian and Coloured) South Africans between 1996 and 2011. African ownership of shares in retirement funds and stock listed on the Johannesburg Stock Exchange has also increased. But other indicators have proved harder to shift. The median monthly income of white South Africans remains over three times that of Africans; the former are approximately five times less likely to be unemployed. Indeed, unemployment has remained stubbornly high throughout the post-apartheid era despite a long period of economic growth only brought to an end by the global downturn of 2008. In 2012 the unemployment rate stood at $36.2 \%$ on the 'expanded' definition which includes a rapidly growing group of discouraged work-seekers who have effectively given up hope of finding a job. Summarising the outcome of the politically radical but economically conservative post-apartheid settlement Colin Bundy (2014: 49) writes:

The evidence is unequivocal. Wealth in South Africa has been partly deracialised. Poverty remains strongly racialised, visited with particular severity upon Africans, at the bottom of the economic pecking order now as they were under apartheid.

In sum then, and recast in terms of Galtung's definition of structural violence quoted earlier, successive post-apartheid governments have been unable, and perhaps insufficiently willing, to use their political power to bring about a radical redistribution in income, wealth and other resources.

\section{Mining and the minerals-energy complex}

Nowhere are the limits of post-apartheid transformation more evident than in the mining industry. Sitting at the heart of the minerals-energy complex, violence has been a defining characteristic of the industry, and of the migrant labour system on which it has depended since first diamonds then gold were discovered in South Africa in the second half of the nineteenth century. Dunbar Moodie (1994) records how assaults on black workers were endemic on the gold mines of the Witwatersrand until the 1970s. When they were underground, migrant workers from Lesotho, Mozambique and what is now South Africa's Eastern Cape province, were subjected to direct, personal violence at the hands of white supervisors and black 'bossboys' straining to meet the production targets on which their bonuses, and the profits of the mining houses, depended. The brutality migrants experienced at work was mirrored by the structural violence built into the single sex compounds in which they lived far from their families in the rural areas (Moodie 1994: 180). Although they were designedoften on explicitly panoptical lines - and run in the interests of maintaining order among the 
workforce (Moodie 1994: 77), the compounds were themselves the sites for further violence in the form of 'faction fights'. While they may have been prompted by concerns over job security and simmering resentments against the tyranny of the 'bossboys', Kynoch (1998: 640 citing work by Harries and Breckenridge) argues that these fights also involved 'the competitive assertion of ethnic and masculine identity' and served important expressive functions in allowing workers to give 'a physical content to their notions of community and a coherence to their sense of justice, hierarchy and self-respect'.

The violence of supervisors and 'bossboys' and the iniquities of the compound system may well be things of the apartheid past, ${ }^{6}$ but mining remains a uniquely dangerous industry and the structural violence associated with the large-scale use of migrant labour persists, albeit in a rather different social and economic context. The Annual Report of South Africa's Mine Health and Safety Inspectorate for 2011-12 illustrates just how hazardous mining continues to be. In 2011 alone, 123 people lost their lives in South African mines at a rate of 0.11 fatality per million hours worked (Chief Inspector of Mines undated: 39, tables 5.2.2 and 5.2.4). Of the eight commodities listed, platinum mining was second only to gold in the number of fatalities (37) and reportable injuries (1,283 out of 3,299 in all mines) recorded, although the rate of fatalities at 0.09 per million hours worked was among the lowest, bettered only by coal and iron ore (ibid.). ${ }^{7}$

Meanwhile, living conditions for migrant mineworkers remain dire. In the immediate aftermath of the $16^{\text {th }}$ August shootings, the investigative journalist Thanuxolo Jika spent six days in Nkaneng, the shack settlement where many of the Marikana strikers lived. He quotes one man, a migrant from Mthatha in the Eastern Cape, thus:

The truth is that we live like pigs while the mine smiles when we dig that platinum and make them rich. We have nothing to show for our long hours of work. We have to provide for ourselves here as well as our families back home. (Jika 2013: 86-7)

As is the case with other informal settlements across the platinum belt to the north and west of Johannesburg - 38 of them in the Rustenburg municipality around Marikana alone - Nkaneng is ' $a$ post-apartheid phenomenon' and reflects the changes that have occurred in the migrant labour system, and the labour practices of mining houses like Lonmin in an era of neo-liberal globalisation (Chinguno 2013: 12). Among these changes is the increasing use of often non-unionised labour employed through a network of brokers and sub-contractors leading two observers to estimate that up to a third of the workforce in the platinum sector may be indirectly employed through third parties (Bezuidenhout and Buhlungu, cited in Chinguno 2013: 13). 
Attempts to end the system of living in ethnically-segregated single sex compound hostels by providing more family-friendly accommodation for the migrant workers who still make up the vast majority of Lonmin's workforce have only succeeded in creating or exacerbating the problems of 'living out' observed by Jika (2013). According to the company's own figures for $2010,83 \%$ of its 28,000 full-time employees were South Africans, but only $18 \%$ came from the local area around the mine defined as the 'Greater Lonmin community' (Chinguno 2013: 8). Unfortunately for the thousands of migrant workers drawn to Marikana and other, similar mines for work, the consequences of offering subsidies and allowances to encourage them to move out of single men's hostels has been to burden them with all the costs of acquiring and maintaining a second home and sometimes a second family too - in a shack settlement near their place of employment (Chinguno 2013; Hartford 2013). Hartford (2013: 160) is damning in his criticism of a 'pattern of migrant labour super-exploitation ... that has remained unaltered in the 18 years of democracy'. Nothing, he argues, has been done either to shorten the migration cycle to enable workers to maintain connections with their families in the rural areas or to increase the remittances on which whole communities in the Eastern Cape and elsewhere rely.

Sadly, the mining industry has remained a prisoner of its apartheid past in this core element of cheap labour sourced through a migrant's punishing annual work cycle and all the social evils associated with [it]. (Hartford 2013: 161)

It is only in the wider context of structural violence built into the migrant labour system in its contemporary form that the actions of the strikers, and the direct violence visited on them by the police, can be fully understood. If the protesters at Sharpeville posed a threat to apartheid's ability to control the movements of an urban African workforce and regulate the number of people coming to join it from the countryside, the strikers at Marikana, and their claims for what they saw as a living wage, represented a challenge to a brutalising system of migrant labour on which Lonmin, other platinum producers and the mining industry more generally continues to depend for its profits. ${ }^{8}$ With this context in mind let me turn now to the second facet of apartheid-era violence to reemerge on $16^{\text {th }}$ August 2012 , the use of lethal force by the police.

\section{Democracy, human rights and community policing (1994 - 1999)}

In this and the next section, I trace developments in policing in the post-apartheid era paying particular attention to the socio-political context in which they took place. At the risk of understating the degree to which post-1994 reforms were the continuation of a 'turn to community' begun as early as the mid-1970s (Super 2013) and implying that the rhetoric, policies and practices of the Mbeki and Zuma governments represent a reversion to the institutionalised brutality of 
apartheid, I will divide the last 20 years into two periods: the first roughly coterminous with Nelson Mandela's time as President; the second dating from 1999 and the appointment of the late Steve Tshwete as Minister of Safety and Security (cf. the analyses and periodisations offered by Bruce (2012), Hornberger (2013), Steinberg (2014) and Marks and Bruce (2014)).

The dark history of apartheid policing documented by Brogden and Shearing (1993) and Brewer (1994) among others forms the background to the first of these periods and, as will become evident later, has its echoes in the police response to a rising tide of popular protests in the second. Investigating this history was part of the mandate of the TRC and fully $87 \%$ of the applications for amnesty received by the Commission from the side of the former government and its security forces were submitted by members of the SAP (Foster et al 2005: 15). However, and notwithstanding the fact that many of the deaths reported by victims of human rights violations and their families in testimony to the Commission arose from public order policing, the vast majority of police applicants came from the Security Branch (ibid). Only two were received in relation to 'riot control' situations. The Commission's discussion of public order policing in its final report may be brief, amounting to no more than 13 pages, but its findings are unambiguous: the SAP, specifically its Riot and Internal Stability Units, 'displayed a gross disregard for the lives and/or physical well-being of ... those engaged in political activity as well as the general public' (Truth and Reconciliation Commission 1999, Volume 2: 174-187). This indifference manifested itself, the report continues,

... in a tendency, often the result of high-level political pressure, to resort to the use of deadly force in situations where lesser measures would have sufficed for the restoration or maintenance of public order. (Truth and Reconciliation Commission 1999, Volume 2: 182)

Read as a response to such trenchant findings the TRC's recommendations on limiting the use of force in controlling crowds verge on the anodyne. They range from ensuring that members are trained to 'international standards' and issued with 'new equipment and apparel' to integrating public order policing into the normal structures of the SAPS (the latter to be done in the interests of restraining any inclination to 'centralise and militarise this function' in the future). Their moderation reflects the Commission's confidence that legislation in the shape of the Regulation of Gatherings Act (No. 205 of 1993) and new SAPS policies on public order policing represented a clear break with the past (Truth and Reconciliation Commission 1999, Volume 5: 331).

The Commission was not alone in its optimism; nor was its confidence entirely misplaced. Writing in 1993, Mike Brogden and Clifford Shearing, for example, had felt able to recommend the approach to public order policing recommended by a multinational panel on the 'Lawful Control of Demonstrations in the Republic of South Africa' chaired by Richard Goldstone as a model for a new 
'dual system of policing'. This involved the police and civil society, public order units and demonstrators, in the co-production of security and peaceful protests (Brogden and Shearing 1993: 182-6). Later, in her unique study of organisational change in the Durban Public Order Policing Unit (POP) in the late 1990s, Monique Marks (2005: 243) reports that even the most cursory review of the Unit in 2001 would confirm that 'real transformation' had taken place. Seven years into the new democracy, Durban POP was 'barely recognisable from what it had been in its former embodiments, the Riot Unit and the Internal Stability Division': more representative (at least in terms of race) of the local population; more relaxed and less military in its style of management; and, perhaps most important of all, more positive in its approach to crowds and much less likely to resort to the indiscriminate use of brute force against protestors (ibid). Marks (2005: 244) attributes this transformation to the changes in the structural conditions of policing brought about since the end of apartheid including the adoption of a new Constitution and supporting legislation committing the renamed SAPS to a community-based approach to policing as a public service to be delivered in accordance with new principles of governance and respect for human rights. ${ }^{9}$ But she also found that the process was by no means untrammelled: some sub-groups within the unit remained resistant to change and opposed to affirmative action as a vehicle for transformation while others clung to unreconstructed attitudes towards both crowds and African township residents (Marks 2005: 245). There was general adherence to the principle of the use of minimum force but there were also times, particularly during crime prevention operations, when beatings were administered and property wrecked in ways reminiscent of the apartheid years - a time which many members recalled with great fondness (Marks, 2005: 245-6).

With the ANC feeling increasingly secure in its hold on political power and confident in the loyalty of the police to a government whose members it had only recently seen as mortal enemies (Dixon 2004), considerable progress was made over the first five years of democracy in turning the SAPS into the rights-respecting, community-oriented, victim-aware organisation contemplated in the Preamble to the South African Police Service Act (No. 68 of 1995). That ordinary black South Africans were able to demand the assistance of the police at times when, in Egon Bittner's (1990: 294) famous words, 'something-is-happening-that-ought-not-to-be-happening-and-about-whichsomeone-had-better-do-something-now' amounted to a fundamental shift in the relationship between police and citizen (Steinberg 2014). That those same citizens could reasonably expect not to be shot at if they chose to exercise their constitutionally-guaranteed right 'peacefully and unarmed, to assemble, to demonstrate, to picket and to present petitions', ${ }^{10}$ and to be treated with a measure of respect when their homes were searched was no less remarkable, even if, as Marks' 
research indicates, the SAPS were not always able to meet the exacting standards of democratic, constitutional policing in practice.

\section{Elite conflicts, crime-fighting and the use of maximum force $(2000-2012)$}

Although considerable progress was made in these early years, crime rates, and those for the most disturbing types of 'contact crime' in particular, continued to rise throughout the late 1990s and in to the early 2000s peaking - if official SAPS figures are to be believed - in 2003 (Presidency 2014). Violent crime, and the state's apparent inability to control it, became the subject of often furious political controversy. Politicians from the ruling party were not slow to reflect the mounting frustration among sections of the public, and within the SAPS itself, with a culture of human rights that was widely seen as constraining the police and hampering their ability to deal with violent criminals. Remarks by the late Steve Tshwete shortly after his appointment as Minister for Safety and Security in Thabo Mbeki's first government about dealing with criminals as a bulldog deals with a bull are often taken as the first of many straws in a wind blowing South African policing back towards a more robust, populist and, for many, popular direction (Bruce 2012; but also see Nyatsumba (1999) for a ringing contemporaneous endorsement of the new Minister's plain-speaking approach).

But this was not all, for what Gillian Hart (2013: 189) calls the 'long decade of the 2000s' from 2001 to 2012 also saw the gradual 'unravelling of ANC hegemony'. One of the most striking features of this period was the increasingly bitter and open competition for key positions - and the power and profits that tended to go with them - not just within the ruling party but in the institutions of national, provincial and local government that the ANC continued to dominate across most of the country. The ousting of Mbeki as President of the ANC in December 2007 and his subsequent replacement as head of state by his long-standing rival Jacob Zuma in May 2009 came to symbolise the extent to which the unity and discipline of the ANC was being eroded even at the highest levels. The effect of these elite and sub-elite conflicts on policing, the rest of the criminal justice system and the very nature of South African democracy, have been subjected to critical scrutiny in recent work by Karl von Holdt (2013) and Jonny Steinberg (2014). Von Holdt (2013: 595) argues that, in the 'fierce competition for access to lucrative contracts', control of the instruments of state coercion and of the investigatory powers of the police - become crucial:

Contestation takes place in and around formal codes and laws, and in the process the law is alternately subverted and wielded by rival contenders. Control over key legal instruments becomes a strategic resource. For those who have transgressed, control holds the prospect 
of immunity. For those seeking the downfall of powerful rivals, control might tip the balance. (Von Holdt 2013: 595)

Commenting on Mbeki's need to maintain control in the face of disagreements within the ruling ANC-led alliance over the increasingly neo-liberal turn in government policy, the expanding influence of a new class of black capitalists and persistent allegations over high-level corruption surrounding a controversial arms deal, Steinberg (2014: 13) makes a very similar point:

To put it bluntly, controlling the agencies that investigated corruption was fast becoming a crucial tool of control inside the ANC. For the question of whom criminal justice agencies went after and whom they left alone became critical to determining who would control the ANC in the near future. The discretion of the leaders of investigative agencies became explosively political.

Similar tensions were manifesting themselves in a growing number of protests about the delivery of services to those who were yet to taste the social and economic benefits of democracy promised in the ANC's oft-repeated election slogan, 'a better life for all'. Figures compiled by Peter Alexander (2010: 27, table 2) from SAPS data show that the number of gatherings involving some form of unrest varied from 622 to 860 between 2004/5 and 2007/8, a rate of roughly two every day. Alternative data for these and subsequent years up to 2011/12 reproduced by von Holdt (2013: 590, Table 1) show signs of fluctuations in response to the rhythms of the electoral cycle and popular perceptions of the leadership of the ANC. But, on any reading of the figures and the more detailed case studies of individual protests put together by von Holdt and his collaborators (2011), there is evidence aplenty to support Alexander's (2010) claim that, for at least the last decade, South Africa has been witnessing a slow-burning, but occasionally insurrectionary, 'rebellion of the poor'.

One of the most striking features of these protests is the role played by the police. A recent study shows that, in six of the seven municipalities for which data was examined, organisers were more likely to give issues relating to crime and the justice system as a reason for holding a protest than corruption, labour relations or service delivery more generally (Grant, 2014). Von Holdt's (2011: 30) overview of the case studies presented in an evocatively titled report on 'insurgent citizenship', The Smoke that Calls, contains a catalogue of police abuses. These include the random use of tear gas and rubber bullets against crowds of protestors and bystanders, beatings and assaults administered to individual protestors, violent incursions into the homes of suspected ringleaders, assaults on their family members, and the detention and torture of those suspected of involvement in protests. In all of the team's research sites policing was 'violent and heavy-handed' and more likely to provoke 
further violence than prevent its recurrence. The cyclical nature of the violence was clear with the two sides, protesters and police, locked into routines redolent of the apartheid era:

Just as much as the protesters drew from the repertoires of anti-apartheid protest, so the police appeared to draw from the repertoires of apartheid-era repression of protest. That is, their actions suggest that the police view protest as a threat to public order rather than as a democratic right which should be protected by the police. (Von Holdt 2011: 30)

If, as the observations of von Holdt and his team suggest, the police have reverted to old habits inimical to the exercise of constitutionally protected rights to demonstrate and protest, what does this tell us about the outcome of the painful process of reform in public order policing documented by Monique Marks? Unfortunately, there is no equivalent of Marks' study to turn to in plotting developments since $2001 .{ }^{11}$ However, we do know that the integration of crime fighting activities into the work of POP units noted by Marks gathered pace as SAPS managers became increasingly concerned about achieving 'value for money' at a time when the number of public protests was perceived to be falling. Two years after the launch of the SAPS' National Crime Combating Strategy in 2000, they were renamed Area Crime Combating Unit (ACCUs) to reflect their responsibilities for fighting crime as well as controlling crowds (Omar 2007: 15-16). Standards of training in public order policing declined and supplies of specialist equipment were cut back (Marks and Bruce 2014). A further restructuring into Crime Combating Units (CCUs) in 2006 saw the number of specialist POP units reduced by almost half from 43 to 23 and the number of trained members by $64 \%$ from 7,227 to 2,595 (Burger 2014). Omar (2007: ix) concludes her study with the prescient warning that the crowd management skills developed since the end of apartheid were in danger of being eroded at a time when, as we have seen, unruly public protests had become a daily occurrence.

The functional conflation of crime fighting with crowd control evident in the metamorphosis of PPUs into CCUs was reinforced in 2009 when new Tactical Response Teams (TRTs) were formed to act as 'force multipliers' in the 'combating of crime and the maintenance of public order' (Bruce 2012: chap. 4). Then, in January 2011, the TRTs were hived off from Crime Prevention into a new Operational Response Services Division along with other specialised units such as the National Intervention Unit and the Special Task Force. The latter had been involved in a series of wellpublicised shoot-outs with members of cash-in-transit heist gangs dating back to December 2007 when 11 people were ambushed and killed at Hammanskraal north of Johannesburg. According to David Bruce (2012), the effects of this merger were felt almost immediately in the police response to community protests in Wesselton, Mpumalanga, when two people were killed, and, more infamously, in the death of Andries Tatane at a protest in Meqheleng near Ficksburg in the Free State. Members of Operational Response Services were involved in both cases and Bruce sees these 
organisational changes, and the deaths that followed them, as intimately connected with the evolution of a policy of maximum force first articulated in public by the then Minister of Police, Nathi Mthethwa (ibid). Speaking on $8^{\text {th }}$ July 2011, Mthethwa sought to draw a distinction "between the need to use maximum force against violent criminals and minimum force in dealing with fellow citizens' (ibid).

There is no need to rehearse the details of Bruce's account here, but three things are worth noting in making the connection between the events at Marikana on $16^{\text {th }}$ August 2012 and the deaths of community protesters, the organisational realignment of public order policing with crime combating and the evolution of a policy that appeared to endorse the use of maximum (up to and including lethal) force in responding to the violent criminals involved in cash-in-transit robberies. ${ }^{12}$ The first is that, as Bruce (2012: chap. 5) points out, it is hard to reconcile the notion of maximum force with s. 13(2)(b) of the South African Police Service Act (No. 68 of 1995). Together with the Constitution, the SAPS Act forms the foundation stone of democratic policing in South Africa and it provides that 'where a member who performs an official duty is authorised by law to use force, he or she may use only the minimum force which is reasonable in the circumstances'. Then there is the police statement issued after the shootings to the effect that specialised units from Operational Response Services had been deployed at Marikana from $13^{\text {th }}$ August (ibid). And finally there is the claim made by none other than the Commissioner of the SAPS, Riah Phiyega, that the police had been obliged to use maximum force to defend themselves against the strikers at Marikana (ibid). It remains to be seen what the Farlam Commission made of all this but it is hard to avoid the conclusion that units with a record of using maximum force in responding to heavily armed robbers resorted to it when confronted by the protestors at Marikana in, pace the strict letter of the law, a permissive political environment. $^{13}$

\section{Conclusion: towards a responsive response to a violent legacy}

Precisely how and why 34 striking miners died at Marikana on $16^{\text {th }}$ August 2012 and who (if anyone) gave the police orders to shoot are questions which, at the time of writing, are yet to be authoritatively answered. The purpose of this article is not to pre-empt the publication of the Farlam Commission's report. Rather it has been to explore the conditions under which so bloody an end to a confrontation between the police and striking workers was possible after almost two decades of constitutional democracy in South Africa. Four factors have been identified, all of them linked in some way both to each other and to a wider failure to deal with the violent legacy of apartheid. In summary, I have argued that the limitations of the TRC's mandate and the emergent neoliberal logic of the post-apartheid democratic settlement have prevented successive governments from tackling the structural violence of apartheid, a form of violence that remains a 
feature of the migrant labour system on which the mining industry, including platinum producers like Lonmin, continues to depend. I have also suggested that the incomplete reform of policing in the 1990s, the partial reversal of some of the changes that were made during this period in the face of persistently high crime rates, the gradual unravelling of the political hegemony of the ANC and its allies, and the conflation of public order policing with combating crime (and violent acquisitive crime in particular) have contributed to a climate in which the use of direct, sometimes fatal, violence by the police has become accepted even, in extremis, expected under a legally dubious doctrine on the use of maximum force.

Against this background, and viewed through the lens provided by Otwin Marenin's (1982) notion of the relative autonomy of the police, the shootings at Marikana can usefully be understood as acts of specific domination. At the macro level, it is something of a commonplace of both police history (not least in South Africa) and comparative studies of policing to observe that the police are more likely to police for specific domination in the interests of a dominant class, 'race' or other social group in unequal, divided societies. This tendency will be particularly pronounced when the interests of that elite are (or are thought to be) threatened by some form of insurrectionary action and when, at the institutional level, mechanisms for the democratic governance of the police are absent or fail to function effectively. Finally, the enforcement of specific domination at the expense of the maintenance of general order will be especially brutal if the police operate in a permissive climate and believe that they have the support, and enjoy the protection, of the ruling elite.

A number of lessons can be learnt from seeing the violence of Marikana in this way. The first is that, as the shortcomings of the TRC illustrate, the nature of structural violence, its association with gross inequalities in power and life chances, its social, ideological and institutional dimensions, and its impact on the lives of those who experience it, must be fully understood before effective action can be taken to tackle it. It follows from this that responsibility for responding to structural violence cannot be delegated to a time-bound and institutionally limited process of national reconciliation. Righting the wrongs that flow from entrenched social and economic (as well as political) injustice must be the core business of government, and a target for all the policy instruments at its disposal, over the medium to long term. And lastly, where direct violence has been routinely used by a state agency such as the police irreversible steps must be taken to change not just the professional dispositions of police officers but the structural conditions under which they work; to paraphrase a famous anti-apartheid slogan, there can be no consistently just public order policing order in an unjust society. On the contrary, the danger is that policing and criminal justice more generally may only serve to compound the effects of gross social inequality by inflicting direct violence on those who have long felt the pain of structural disadvantage. 


\section{References}

Alexander, P. (2010) 'Rebellion of the poor: South Africa's service delivery protests - a preliminary analysis', Review of African Political Economy, 37(123): 25-40.

Alexander, P. (2012) 'The massacre: a narrative account based on workers' testimonies' in Alexander, P., Sinwell, L., Lekgowa, T., Mmope, B. and Xezwi, B., Marikana: A View from the Mountain and a Case to Answer. Jacana.

Alexander, P. (2013) 'Marikana, turning point in South African history', Review of African Political Economy, 40:138, 605-619.

Alexander, P., Sinwell, L., Lekgowa, T., Mmope, B. and Xezwi, B. (2012) Marikana: A View from the Mountain and a Case to Answer. Jacana.

Ashman, S., Fine, B. and Newman, S. (2011) 'Amnesty International? The Nature, Scale and Impact of Capital Flight from South Africa', Journal of Southern African Studies, 37(1): 7-25.

Bittner, E. (1990) Aspects of Policing. Northeastern Univeristy Press.

Brewer, J. (1994) Black and Blue: Policing in South Africa. Oxford: Oxford University Press.

Brogden, M. and Shearing, C. (1993) Policing for a New South Africa. London: Routledge.

Bruce, D. (2012) Marikana and the Doctrine of Maximum Force. [Kindle edition] Johannesburg: Parktown Publishers.

Bundy, C. (2014) Short-Changed? South Africa since Apartheid. Johannesburg: Jacana.

Burger, J. (2014) 'The South African Police Service must renew its focus on specialised units', ISS Today, $31^{\text {st }}$ March. [Available at: http://www.issafrica.org/iss-today/the-south-african-policeservice-must-renew-its-focus-on-specialised-units. Accessed $5^{\text {th }}$ September 2014.]

Calland, R. (2013) The Zuma Years: South Africa's Changing Face of Power. Zebra. 
Chief Inspector of Mines (undated) Mine Health and Safety Inspectorate, Annual Report 2011/2012. Arcadia: Department of Mineral Resources. [Available at:

http://www.sacea.org.za/.\%5Cdocs\%5CDMR 2012.pdf. Accessed $22^{\text {nd }}$ June 2014.]

Chinguno, C. (2013) Marikana and the post-apartheid workplace order. Working Paper 1, Society, Work and Development Institute (SWOP), University of the Witwatersrand. Johannesburg: SWOP.

Dixon, B. (2004) 'Community policing: 'cherry pie' or melktert? Society in Transition, 35(2): 251-272.

Dixon, B. (2013) 'Waiting for Farlam: Marikana, social inequality and the relative autonomy of the police', South African Crime Quarterly, 46: 5-11.

Dlagamandla, F., Jika, T., Ledwaba, L., Mosamo, S., Saba, A. And Sadiki, L. (2013) We Are Going to Kill Each Other Today: The Marikana Story. Tafelberg.

Fine, B. and Rustomjee, Z. (1996) The Political Economy of South Africa: From Mineral-Energy Complex to Industrialization. Hurst.

Foster, D., Haupt, P. and De Beer, M. (2005) The Theatre of Violence: Narratives of Protagonists in the South African Conflict. HSRC Press/James Currey.

Frankel, P. (2001) An Ordinary Atrocity: Sharpeville and Its Massacre. Yale University Press.

Frankel, P. (2013) Between the Rainbows and the Rain: Marikana, Migration, and the Crisis of Modern South Africa. Agency for Social Reconstruction.

Galtung, J. (1969) 'Violence, peace, and peace research', Journal of Peace Research, 6(3): 167-191.

Grant, L. (2014) 'Taking to the streets: who is protesting and why?', Mail \& Guardian, $28^{\text {th }}$ April. [Available at http://mg.co.za/data/2014-04-28-taking-to-the-streets-who-is-protesting-and-why. Accesssed $27^{\text {th }}$ June 2014.]

Gready, P. (2011) The Era of Transitional Justice: The Aftermath of the Truth and Reconciliation Commission in South Africa and Beyond. Routledge. 
Habib, A. (2013) South Africa's Suspended Revolution: Hopes and Prospects. Witwatersrand University Press.

Hamber, B. (1998) 'Dr Jekyll and Mr Hyde: violence and transition in South Africa', in Bornman, E., Van Eeden, R. and Wentzel, M. (eds) Violence in South Africa. Human Sciences Research Council. [Available at http://www.csvr.org.za/index.php/publications/1712-dr-jekyll-and-mr-hyde-violenceand-transition-in-south-africa.html. Accessed $19^{\text {th }}$ June 2014]

Hart, G. (2013) Rethinking the South African Crisis: Nationalism, Populism, Hegemony. University of KwaZulu-Natal Press.

Hartford, G. (2013) 'The mining industry strikes: causes - and solutions?' in Dlagamandla, F., Jika, T., Ledwaba, L., Mosamo, S., Saba, A. And Sadiki, L. (2013) We Are Going to Kill Each Other Today: The Marikana Story. Tafelberg.

Hornberger, J. (2011) Policing and Human Rights: The Meaning of Violence and Justice in the Everyday Policing of Johannesburg. Routledge.

Hornberger, J. (2013) 'From General to Commissioner to General-on the popular state of policing in South Africa', Law \& Social Inquiry, 38 (3): 598-614.

Jika, T. (2013) 'Life in a time of violence', in Dlagamandla, F., Jika, T., Ledwaba, L., Mosamo, S., Saba, A. And Sadiki, L. (2013) We Are Going to Kill Each Other Today: The Marikana Story. Tafelberg.

Kasrils, R. (2013) 'How the ANC's Faustian pact sold out South Africa's poorest', The Guardian, $24^{\text {th }}$ June. [Available at http://www.theguardian.com/commentisfree/2013/jun/24/anc-faustian-pactmandela-fatal-error. Accessed $20^{\text {th }}$ June 2014]

Kynoch, G. (2008) 'Urban violence in colonial Africa: a case for South African exceptionalism', Journal of Southern African Studies, 34(3): 629-645.

Ledwaba, L. (2013) "We are ending this today" in Dlagamandla, F., Jika, T., Ledwaba, L., Mosamo, S., Saba, A. and Sadiki, L. We Are Going to Kill Each Other Today: The Marikana Story. Tafelberg. 
Lodge, T. (2011) Sharpeville: An Apartheid Massacre and Its Consequences. Oxford University Press.

Louw, A. and du Plessis, A. (2005) 'Crime and crime prevention in South Africa: 10 years after', Canadian Journal of Criminology and Criminal Justice, 47(2): 427-446.

Marais, H. (2011) South Africa Pushed to the Limit: The Political Economy of Change. London: Zed.

Marenin, O. (1982) 'Parking tickets and class oppression: the concept of policing in critical theories of criminal justice', Contemporary Crises, 6: 241-266.

Marikana Commission (2014) Heads of Argument of Evidence Leaders. [Available at:

http://www.marikanacomm.org.za/docs/201411-HoA-EvidenceLeaders.pdf. Accessed $14^{\text {th }}$ Mary 2015.]

Marks, M. (2005) Transforming the Robocops: Changing Police in South Africa. University of KwaZulu-Natal Press.

Marks, M. and Bruce, D. (2014) ‘Groundhog Day? Public order policing twenty years into democracy', South African Journal of Criminal Justice, 3: 346-376.

Marks, M. and Wood, J. (2010) 'South African policing at a crossroads: the case for a 'minimal' and 'minimalist' public police', Theoretical Criminology, 14(3): 311-329.

Maromo, J. (2014) 'Marikana strategy 'same as Sharpeville”, IOL News, $26^{\text {th }}$ March. [Available at http://www.iol.co.za/news/special-features/marikana-strategy-same-as-sharpeville1.1666724\#.U6HASpRdV8E. Accessed $18^{\text {th }}$ June 2014]

Moodie, T.D. with Ndatshe, V. (1994) Going for Gold: Men, Mines, and Migration. University of California Press.

Moyo, F. (2013) 'The F-word: Marikana not like Sharpeville tragedy', City Press, $22^{\text {nd }}$ July. [Available at http://www.citypress.co.za/columnists/the-f-word-marikana-not-like-sharpeville-tragedy/. Accessed $19^{\text {th }}$ June 2014] 
Omar, B. (2007) SAPS' Costly Restructuring: A Review of Public Order Policing Capacity. ISS Monograph No. 138. Institute for Security Studies.

Nyatsumba, K. (1999) 'Let's take the fight to the criminals', IOL News, $14^{\text {th }}$ July. [Available at: http://www.iol.co.za/news/south-africa/let-s-take-the-fight-to-the-criminals1.4890\#.U6vnNpRdV8E. Accessed $26^{\text {th }}$ June 2014.]

Posel, D. (2002) 'The TRC Report: What kind of history? What kind of truth?' in Posel, D. and Simpson, G. (eds.) Commissioning the Past: Understanding South Africa's Truth and Reconciliation Commission. Witwatersrand University Press.

Posel, D. and Simpson, G. (2002) Commissioning the Past: Understanding South Africa's Truth and Reconciliation Commission. Witwatersrand University Press.

Presidency, Republic of South Africa (2014) Twenty Year Review: South Africa 1994-2014. [Available

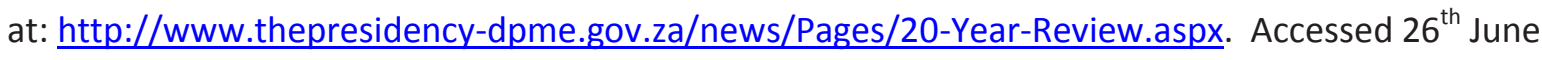
2014.]

Presidency, Republic of South Africa (2015) President Zuma to release Marikana report. [Available at: http://www.marikanacomm.org.za/docs/20150510-ms-report.pdf. Accessed $14^{\text {th }}$ May 2015.]

Rauch, J. (2000) 'Police reform and South Africa's transition', Paper presented at the South African Institute of International Affairs Conference. [Available at:

http://www.csvr.org.za/wits/papers/papsaiia.htm. Accessed 24 ${ }^{\text {th }}$ June 2014.]

Safe Work Australia (undated) Mining [Available at:

http://www.safeworkaustralia.gov.au/sites/SWA/about/Publications/Documents/432/Mining-FactSheet-2011-12.pdf. Accessed 21 $1^{\text {st }}$ June 2014.]

SAPA-AFP (2013) 'Lonmin swings back to annual profit', City Press, $11^{\text {th }}$ November. [Available at: http://www.citypress.co.za/business/lonmin-swings-back-annual-profit/. Accessed $22^{\text {nd }}$ June 2014.] Saul, J. and Bond, P. (2014) South Africa - The Present as History from Mrs Ples to Mandela and Marikana. James Currey.

Shaw, M. (2002) Crime and Policing in Post-Apartheid South Africa: Transforming under Fire. Hurst. Simpson, G. (2002) 'Tell no lies, claim no easy victories: a brief evaluation of South Africa's Truth and Reconciliation Commission', in Posel, D. and Simpson, G. (eds.) Commissioning the Past: Understanding South Africa's Truth and Reconciliation Commission. Witwatersrand University Press. 
Smith, D. (2012) 'Marikana mine shootings revive bitter days of Soweto and Sharpeville', The Guardian, $7^{\text {th }}$ September. [Available at: http://www.theguardian.com/world/2012/sep/07/marikanamine-shootings-revive-soweto. Accessed $18^{\text {th }}$ June 2014]

Steinberg, J. (2008) This Blue: The Unwritten Rules of Policing South Africa. Jonathan Ball.

Steinberg, J. (2014) 'Policing, state power, and the transition from apartheid to democracy: a new perspective', African Affairs 113 (451):173-191.

Super, G. (2013) Governing through Crime in South Africa: The Politics of Race and Class in Neoliberalizing Regimes. Ashgate.

Tait, S. and Marks, M. (2011) 'You strike a gathering, you strike a rock: current debates in the policing of public order in South Africa', South African Crime Quarterly, 38: 15-22.

Terreblanche, S. (2012) Lost in Transformation: South Africa's Search for a New Future since 1986. KMM Review Publishing.

Truth and Reconciliation Commission (1999) Truth and Reconciliation Commission of South Africa Report, Volumes 1-5. Macmillan.

Von Holdt, K. (2011) 'Overview - Insurgent citizenship and collective violence: analysis of case studies' in Von Holdt, K., Langa, M., Molapo, S., Mogapi, S., Ngubeni, K., Dlamini, J. and Kirsten, A. (eds.) The Smoke that Calls: Insurgent citizenship, collective violence and the struggle for a place in the new South Africa. Centre for the Study of Violence and Reconciliation/Society, Work and Development Institute, University of the Witwatersrand.

Von Holdt, K. (2013) 'South Africa: the transition to violent democracy', Review of African Political Economy, 40 (138): 589-604.

Von Holdt, K., Langa, M., Molapo, S., Mogapi, S., Ngubeni, K., Dlamini, J. and Kirsten, A. (2011) The Smoke that Calls: Insurgent citizenship, collective violence and the struggle for a place in the new South Africa. Centre for the Study of Violence and Reconciliation/Society, Work and Development Institute, University of the Witwatersrand.

\footnotetext{
${ }^{1}$ The TRC was set up to analyse and describe the causes, nature and extent of gross violations of human rights committed between $1^{\text {st }}$ March 1960 and $10^{\text {th }}$ May 1994 (Truth and Reconciliation Commission 1999: vol. 1, para. 32). The account of the 'Sharpville (sic) massacre' is from paragraph 48 of Volume 3.
} 
${ }^{2}$ The Commission submitted its report to President Jacob Zuma on $31^{\text {st }}$ March 2015. At the time of writing, it had been not been published while the President considers its findings and it was unclear when the report would be made public: a statement issued by the Presidency on $10^{\text {th }}$ May 2015 gave no date for its publication stating only that it would be released 'in due course' (Presidency 2015).

${ }^{3}$ This view of the insurrectionary nature of the strikers' action is consistent with that taken by the evidence leaders in their heads of argument submitted to the Commission at the conclusion of the Inquiry in November 2014 (Marikana Commission 2014). Until the report of the Commission is published, these heads of argument constitute the most authoritative and disinterested account of the background to the events of $9^{\text {th }}-16^{\text {th }}$ August 2012 that formed the main focus of the Inquiry's work.

${ }^{4}$ Galtung (1969: 168) defines violence capaciously as being present 'when human beings are being influenced so that their actual somatic and mental realizations are below their potential realizations'.

${ }^{5}$ The origins of the MEC are traced in Fine and Rustomjee (1986). It became a feature of the South African economy in the 1950s and 1960s during the consolidation of apartheid and consisted of 'a corporate conglomeration that focused on minerals production (and some processing), energy provision, chemicals and finance - all of it capital-intensive' (Marais 2011: 19). Crucially, the evolution and success of the MEC was dependent on the support of the state, most notably in the supply of cheap energy.

${ }^{6}$ Alexander (2014: 607) notes that (often white) managers continue to be focused on production targets, show workers a lack of respect and have adversarial attitudes towards them.

${ }^{7}$ The data for occupational diseases ranging from silicosis through pulmonary tuberculosis to noiseinduced hearing loss reported elsewhere in the report make equally sorry reading. Directly comparable data on mine safety is hard to come by but it is worth noting that for the five years 2007-8 to 2011-12 a total of 36 Australian mining workers died from work-related injuries (Safe Work Australia undated).

${ }^{8}$ It is worth noting at this point that Lonmin plc returned to profit in the financial year ending September 2013. Revenues fell $5.8 \%$ to $\$ 1.52$ billion from the previous year, but earnings after tax stood at $\$ 166$ million compared with a net loss of $\$ 410$ million in 2011/2012 (SAPA-AFP 2013).

${ }^{9}$ See Rauch (2000); Shaw (2002); Dixon (2004) and Louw and du Plessis (2005) for accounts of the wider process of police reform over this period. 
${ }^{10}$ These words are taken from section 17 of the Bill of Rights set out in the Constitution of the Republic of South Act No. 108 of 1996.

${ }^{11}$ See Tait and Marks (2011) and Marks and Bruce (2014) for fuller discussions of developments in public order policing over this period.

${ }^{12}$ In a more recent intervention in the debate Marks and Bruce (2014) note that between Minister Nthethwa's speech on $8^{\text {th }}$ July 2011 and the shootings at Marikana just over a year later, the SAPS had sought to withdraw the TRTs from policing public protests and restore the primacy of POP specialists in managing crowds. Against this background they are agnostic as to whether Marikana represents an aberrant return to an already discredited approach or a predictable disaster waiting to happen.

${ }^{13}$ It should be noted at this point that, in their heads of argument, the evidence leaders to the Inquiry, were unsparing in their criticism of the strategic and operational direction of the SAPS in the week 9th - 16th August and the conduct of individual members of the TRT and other units on the ground at Marikana needs to be evaluated in the context of a catastrophic failure of leadership on the part of their superiors (Marikana Commission 2014). 